\title{
EL RETABLO MAYOR DE LA CAPILLA DE LA VERA CRUZ DE MARCHENA (SEVILLA)
}

\section{THE MAIN ALTARPIECE AT THE VERA CRUZ CHAPEL IN MARCHENA (SEVILLE)}

\author{
Manuel Antonio Ramos SuÁrez \\ Universidad de Sevilla. España \\ ORCID: 0000-0001-8397-6532 \\ mantonioramos@us.es
}

\begin{abstract}
En este trabajo se analizan los retablos que poseyó la hermandad del Señor de la Santa Vera Cruz de la localidad de Marchena. Se define el actual retablo como obra de Tomás Guisado el Joven y se hace un análisis de su evolución estilística. El proceso de restauración a que se vio sometido el retablo a fines del año 2010 permitió hacer su análisis y estudio histórico-artístico.

Palabras clave: retablo; barroco; hermandad de la Vera Cruz; Tomás Guisado el Joven; Luis de Figueroa.
\end{abstract}

This paper analyzes the altarpieces that the Brotherhood of the Lord of the Holy Vera Cruz in the town of Marchena have possessed. The current altarpiece is defined as the work of Tomás Guisado el Joven and an analysis of his stylistic evolution is made. The restoration process to which the altarpiece was subjected at the end of 2010 allowed to make its analysis and historical-artistic study.

Keyboard: altarpiece; Baroque; Brotherhood of the Vera Cruz; Tomás Guisado el Joven; Luis de Figueroa.

Cuando se acomete la restauración de un bien mueble o inmueble se ofrece una oportunidad propicia para investigar aspectos desconocidos de su historia y construcción. Ese estudio permite efectuar un acercamiento a la historia del mismo, conocer las razones de su realización, personas que intervienen, procedimiento de financiación, artistas diseñadores y operarios, así como las transformaciones que sufre a lo largo del tiempo, entre otros. De igual modo, esa investigación se convierte en una herramienta útil para hacer una lectura lo más fidedigna posible del bien cultural antes de acometer la restauración. Hace algunos años se 
restauró el retablo que nos ocupa, y se carecía de fuentes de información para reconstruir su historia material. La falta de documentación tanto del convento de San Francisco como de los libros de actas y cuentas de la hermandad no lo permitía. Ha sido gracias a fuentes indirectas y a los datos que aporta el propio retablo lo que ha permitido reconstruir parte de su pasado.

Se desconoce cómo pudo ser el primer retablo que albergó la imagen del Crucificado de la Vera Cruz. Sin embargo, teniendo en cuenta que la imagen titular está fechada a mediados del siglo XVI y que está atribuida a Roque Balduque, todo hace suponer que, desde que se trajo la imagen a la capilla del convento y hasta el año 1622 en que se hizo un nuevo retablo, debió estar ubicada en un retablo sencillo. Lo cierto es que en mayo del mencionado año, Lorenzo de Saavedra y Alonso Jiménez, rector y mayordomo de la hermandad, concertaron un retablo con Luis de Figueroa, escultor y arquitecto de retablos, vecino de la collación de la Magdalena en Sevilla ${ }^{1}$. Su estancia en la villa, para contratar la construcción de dos monumentos, uno para la parroquia de San Miguel y otro para la de San Sebastián, así como la realización de un retablo dedicado al Dulce Nombre de Jesús o Niño perdido en el convento de San Pedro Mártir ${ }^{2}$, debió servir para que también contratara el retablo. Según el documento notarial, el retablo debía hacerse de madera de borne o de cedro, con seis varas de alto $(5,16 \mathrm{~m})$ hasta el pie de la cruz que lo remataría y cuatro varas de ancho $(3,44 \mathrm{~m})$ "sin los vuelos". Siguiendo las trazas realizadas por el artista, el nicho del Crucificado debía tener tres varas de alto $(2,58 \mathrm{~m})$, dos de ancho menos una sexta parte $(1,58 \mathrm{~m})$ y media vara menos cuatro dedos de fondo ( $0,40 \mathrm{~m}$ aproximadamente). Respecto a la distribución de elementos sustentantes y decorativos, el retablo tendría dos pilastras a ambos lados del camarín del Cristo, el banco debía llevar "sus frisos con sus medias cañas" y "sus cestones de frutas" y la cabeza, que debía referirse al ático, llevaría "sus ménsulas y sus oyas de haia" decorada con los motivos que aparecían en las trazas. El retablo se construyó en la casa del artista en Sevilla, que se desplazó a la localidad para su colocación con cargo a la hermandad. El coste del retablo ascendió a 1.200 reales, que se pagaron en dos partes, 600 reales al comenzar la obra y el resto cuando el retablista lo armase y asentase en la capilla. Entre los testigos figuraban vecinos de la localidad como Sebastián Alonso de Vega, Juan de Benjumea Buzón o el presbítero Luis de Molina ${ }^{3}$. Aunque debía concluirse para diciembre, no se entregó hasta junio de 1623, fecha en la que Figueroa dio carta de pago a Alonso Jiménez, mayordomo de la hermandad, por la obra de "talla y samblaje de un crucifijo" por un total de 1.200 reales según la escritura que pasó ante Juan

\footnotetext{
${ }^{1}$ Para conocer la vida y obra de Luis de Figueroa, Halcón/Herrera/Recio, 2009: 185-187.

2 Ramos Suárez, 2017: 189-221.

${ }^{3}$ Mira Caballos/De la Villa Nogales, 1993: 76-77. El retablo se concertó el 23 de mayo.
} 
Bautista de Contreras en Sevilla el día 30 de junio de $1623^{4}$. El dato de este pago origina dudas de si Figueroa concertó el mismo día la realización de un retablo y un Crucificado. No obstante, tras consultar la documentación notarial de Marchena y observar que ese día el artista tan solo contrató el retablo y dos monumentos para las iglesias de San Sebastián y San Miguel $^{5}$, pensamos que el notario protocolizó erróneamente la escritura haciendo referencia a un Crucificado y no al retablo. Posteriormente, fue Gestoso quien arrastró el error al referirse a la escritura sin reparar en cotejarla con las realizadas en la localidad de Marchena. Además, la cantidad mencionada coincide con la presupuestada para el retablo. Un análisis del actual retablo corrobora que Figueroa construyó ese retablo para la hermandad. Lo atestiguan algunas piezas que fueron reaprovechadas para el retablo barroco, más en la línea estética del primer tercio del siglo XVII que en la forma de trabajar de mediados del siglo XVIII. Entre los restos que se conservan por detrás de la estructura del retablo están un baquetón y una tabla dorada cerrando la parte superior del sagrario y el nicho u hornacina del Crucificado, cuyas medidas actuales están dentro de las contratadas. (Figura 1).

Transcurrido un siglo desde que se construyó el retablo y siendo José Jiménez Suárez y Alonso de Castroviejo rector y mayordomo de la hermandad, decidieron ampliar el nicho para colocar al Señor de la Vera Cruz en una nueva cruz ${ }^{6}$. Así se recoge en la contabilidad de la hermandad durante los años 1726 y $1727^{7}$.

${ }^{4}$ Así lo citaba Gestoso, 1889: 146. La escritura está deteriorada en algunas partes del documento. Para conocerla, Archivo Histórico Provincial de Sevilla (AHPSe), Protocolos Notariales, leg. 4289, f. 924r-v.

${ }^{5}$ El legajo de protocolos notariales donde figuran esas escrituras aparece foliado con la antigua numeración y no se aprecia ninguna laguna. Archivo Histórico de Protocolos Notariales de Marchena (APNM), leg. 147, ff. 268v-270v.

${ }^{6}$ Debe tratarse de una cruz de madera dorada y estofada anterior a la actual de plata. La cruz de plata debió realizarse en los años 1734 y 1735, tal como se deduce de las cuentas de ese año. Fue costeada con las limosnas entregadas por los hermanos, entre los que se señalaron las aportaciones de la familia Guillén Galindo entre otras. El importe de la cruz ascendió a 1.712 reales y medio, según se deriva de un apunte por el "gasto en plata y hechura de la chruz" que se le hizo al Cristo. Archivo de la Hermandad de la Vera Cruz de Marchena (AHVCM), Libro de quentas de la cofradia de la Santa Vera Crus. Años 17221767, Data de los años 1734-1735, s. f. Con posterioridad, le debieron añadir las veneras de los extremos.

${ }^{7}$ Ese mismo año la cofradía celebró una fiesta de toros el miércoles 23 de julio, si bien en la documentación del cabildo municipal, que dio permiso para su celebración, no consta el motivo de realización de la misma. Archivo Municipal de Marchena (AMM), Actas Capitulares, leg. 13, año 1727, f. 66v. Cabildo celebrado el 21 de julio de 1727. Curiosamente, por entonces José de Ayllón, rector de la hermandad, era regidor del cabildo municipal. 
Finalmente solo se amplió en altura ${ }^{8}$. Los costes de agrandar el nicho ascendieron a 25 reales con 24 maravedíes. Además, se compró un lienzo para tapar la peana del Cristo, un velo de gasa y forro y otro velo de tafetán, todos de color verde, para velar la imagen durante los días del año que no estaba expuesta a la veneración de los fieles ${ }^{9}$. Al año siguiente se pagaron 100 reales al pintor Juan Pérez por la pintura de seis blandones ${ }^{10}$.

En el primer tercio del siglo XVIII, la hermandad se planteó la construcción de un nuevo retablo, no sabiéndose si era para sustituir el retablo mayor o para albergar otra imagen de la hermandad. El apunte, recogido en el libro de cuentas de los años 1731 a 1732, es muy sucinto: "Ytem quarenta reales que se gastaron en el testimonio que se trajo de Osuna de que Castillo no proseguía el retablo en que van incluso el alquile de un cavallo del [perdido] que llevo"11. Por tanto, de ser así, se estaría ante un retablo de estética barroca, que un tal Castillo estaba construyendo, o quizás proyectando para la hermandad, quien decidió no continuar con el trabajo. Se desconoce quién pudo ser y se ignora su grado de implicación, si hizo las trazas o participó en la obra material del mismo. Para esas fechas, es probable que en la localidad de Osuna estuviese en activo el retablista Juan del Castillo, quien con anterioridad trabajó en la villa de Marchena ${ }^{12}$, si bien ya tendría una avanzada edad. Aquel retablo no se materializó, pues en los libros contables de la hermandad no se recoge ningún desembolso económico por este concepto. En las cuentas justificadas entre los años 1741 y 1742 por el mayordomo Salvador de Luque, se pagaron 20 reales por cinco badanas para el altar del Señor ${ }^{13}$.

${ }^{8}$ Las medidas son las siguientes: altura, antes $258 \mathrm{~cm}$, ahora $298 \mathrm{~cm}$; anchura, antes $158 \mathrm{~cm}$, ahora $172 \mathrm{~cm}$; y de fondo, antes $43 \mathrm{~cm}$, ahora $50 \mathrm{~cm}$.

9 AHVCM, Libro de quentas..., Data de los años 1726-1727, s. f. Los costes del nicho incluían la madera, clavos y mano de obra. Además se gastaron cerca de 200 reales en los velos para el camarín. Aunque actualmente es común ver a las imágenes así, antes estaban veladas la mayor parte del año y se descubrían corriendo unas cortinillas o velos que tenían delante.

10 AHVCM, Libro de quentas..., Datas de los años 1727-1728, s. f., data $n^{\circ} 12$. El mismo artista pintó la vara de la manguilla. Data $n^{\circ} 13$.

11 AHVCM, Libro de quentas..., Data de los años 1731-1732, s. f. Carmona Perea, 2010: 78.

12 Para conocer su obra en Marchena, Arenillas, 1989: 81-84. Ramos Suárez, 2001: 259-274

13 AHVCM, Libro de quentas..., Data de los años 1741 a 1742, s. f., data $n^{\circ} 8$. Los años anteriores a esta década, concretamente ya en 1734 y hasta mayo de 1738, fueron años en los que se afianzó la devoción local al Cristo de la Vera Cruz y a la Virgen de la Esperanza ofreciéndoles rogativas, novenario y procesión por la salud pública y rogativas por lluvia. Así se hizo constar en la carta que presentó la hermandad al cabildo municipal, leyéndose en la sesión del cabildo donde acordaron entregar 100 reales a la corporación 
Fue a partir del año 1752 cuando la hermandad abonó una cantidad considerable para construir un nuevo retablo que viene a corresponderse con el que actualmente tiene: "Primeramente se le reciben en data dies y ciete mil y quinientos reales de vellón los mismos que se distribuieron y gastaron en fabricar y hacer el retablo que oi subsiste en la capilla desta hermandad y donde se halla colocado [perdido] [Crucifi]cado de esta educación [perdido]... 17.500"14. Tras el pago mencionado, se volvieron a abonar un total de 525 reales que correspondían a un reparo en el arco del nicho del Señor ${ }^{15}$. Por tanto, el coste del retablo ascendió a 18.025 reales $^{16}$. Esta cantidad era desproporcionada para la economía de la hermandad, pues sus ingresos y gastos eran de unos 3.000 o 4.000 reales al año. Para que la hermandad abordase un pago de ese montante, se contó con la aportación de limosnas de algunas familias pudientes, caso de la familia Cortina representada en Pedro ${ }^{17}$ o Nicolás Cortina ${ }^{18}$, Juan López y su esposa ${ }^{19}$, José Aguilar y Galindo ${ }^{20}$ o el mismo duque de $\operatorname{Arcos}^{21}$, lográndose recaudar junto a otras donaciones un total de 4.959 reales. De este modo, quedaron pendientes de pagar un total de 13.066 reales y fue José Hidalgo, mayordomo de la hermandad, quien cargó con todo el gasto después de que los hermanos aportasen sus donativos. Así, se deduce de un apunte que se hace en el margen del libro contable ${ }^{22}$. El mayordomo pagó esa cantidad, entregándola de limosna a la hermandad y prometiendo que en ningún momento ni él mismo, ni sus hijos, ni herederos la reclamarían a la corporación ${ }^{23}$.

para costear los mencionados cultos. AMM, Actas Capitulares, leg. 13, f. 25r. Cabildo celebrado el 8 de mayo de 1738. AMM, Propios, leg. 112, f. 442r-v.

${ }^{14}$ AHVCM, Libro de quentas..., Data de los años 1752 a 1754, s. f.

${ }_{15}$ El deterioro del libro de cuentas citado con anterioridad dificulta la visión del apunte.

16 AHVCM, Libro de quentas..., Cargo del año 1753, s. f.

${ }_{17}$ AHVCM, Libro de quentas..., Cargo del año 1753, s. f. Aportó 135 reales. También se hizo constar este apunte: "Ytem se le hiso cargo de seiscientos reales vellón que mandó y libro en los proprios desta villa don Pedro Cortinas que santa gloria aia... 600".

18 AHVCM, Libro de quentas..., Cargo del año 1753, s. f. Ingresó una cantidad de 40 reales.

19 AHVCM, Libro de quentas..., Cargo del año 1753, s. f. Aportó una cantidad de 120 reales.

20 AHVCM, Libro de quentas..., Cargo del año 1753, s. f. Entregó 720 reales de limosna.

${ }^{21}$ Por entonces, quien ostentaba el título de duque de Arcos era don Francisco Ponce de León y Spínola. Dio 300 reales de limosna a la hermandad.

${ }^{22}$ AHVCM, Libro de quentas..., Cargo del año 1753, s. f. "De los 13. [perdido 06] 6 reales que resultan a favor de Joseph Hidalgo [perdido] mitio y perdonó los 12.191 y solo se le a [perdido] fazer, 875 [perdido]."

23 AHVCM, Libro de quentas..., Cargo del año 1753, s. f. "[...] ante mi el presente escribano y testigos que irán nominados que los remitía dava de limosna y los perdonaba a 
En el año 1756, se pagaron 450 reales por la construcción de cuatro candeleros que se hicieron para el altar del Señor ${ }^{24}$. Posteriormente, tal como se recoge en una leyenda que corre por el banco del retablo, este se concluyó y se terminó de dorar en el año 1759: "SE ACAVO ESTA OBRA DE MADERA I DORADO SIENDO DIGNMO RECTOR DN NICOLAS DE LA CORT [...]... SIENDO RETO DN IVAN, GALINDO... A EXPENSAS DE LAS [DEMANDAS] I LOS BIENHECHORES SIENDO FISCAL DON IGNACIO SEGURA JOSEPH HIDALGO MAIORDOMO DN MIGUE DE LA MADID ESCRIVANO AÑO DE 1759 A D" ${ }^{25}$. Gracias a la lectura de esa leyenda se puede conocer parte de la vida de los hermanos de la corporación que colaboraron o fueron protagonistas de la construcción del retablo. El primer personaje, que aparece como dignísimo rector, es Nicolás de Cortina. Debe tratarse del presbítero Nicolás Díez de la Cortina. Aunque fue hermano mayor desde los años 1755 a 1757, su nombre aparece asociado a dignísimo rector ${ }^{26}$. Se ordenó como presbítero en marzo de $1747^{27}$, y estaba muy bien considerado en la localidad ${ }^{28}$. Según un padrón vecinal del año 1753, vivía en la plaza de San Juan ${ }^{29}$. Años más tarde, en abril de 1782, pidió al cabildo municipal la concesión de unos terrenos frente a la iglesia de San Juan para edificar su nueva casa-palacio en dicho lugar ${ }^{30}$. Falleció en mayo de 1797 y fue enterrado en la parroquia de San Juan Bautista de la localidad $^{31}$. El libro de cuentas de la hermandad registra que quien ocupaba el cargo

dicha hermandad y se obligava y obligó ahora ni en tiempo alguno reclamara ni demandara a la zitada hermandad por la referida cantidad el susodicho ni sus herederos y si lo intentaren quiere no ser oído en juicio ni los derechos sus herederos, sino [perdido] injustos litigantes [perdido] computen y por el [perdido]".

${ }^{24}$ AHVCM, Libro de quentas..., Cargo del año 1753, s. f.

${ }_{25}$ Lo que aparece entre corchetes es ilegible.

${ }^{26}$ AHVCM, Libro de quentas..., Ingreso de los años 1755 a 1757, s. f. Etimológicamente, en la localidad, el cargo de rector corresponde al de hermano mayor de una hermandad.

${ }^{27}$ Institución Colombina (IC), Archivo General del Arzobispado de Sevilla (AGAS), II. Gobierno, Visitas, caja 5156, s. f.

${ }^{28}$ IC, AGAS, II. Gobierno, Visitas, caja 5227, s. f. En la visita del año 1769, se decía que era "hombre rico, manda mucho en sus haciendas y campo pero sin otra nota. Antes si buena capacidad, da muchas limosnas y bien gusto en el pueblo".

29 AMM, Padrones, leg. 1305, Padrón del año 1753, f. 14v. Se inscribe así: “n. 208. Don Nicolás Diez de la Cortina presbítero hijo lexítimo del dicho don Pedro" (Díez de la Cortina y Agüero).

${ }^{30}$ Para conocer lo ocurrido y una descripción de la casa, actual calle San Juan $n^{\circ} 6$, Arenillas, 1990: 79-80.

31 Archivo Parroquial de San Juan Bautista de Marchena (APSJM), Defunciones, lib. 16, ff. 144v-145r. Se enterró el día 25 de ese mes y año con funeral general de clero por la hermandad de sacerdotes de San Pedro ad Vincula establecida en la misma parroquia. El día 29 de mayo se le hicieron honras generales del clero por su alma. Mi agradecimiento al 
de rector era Juan Aguilar Galindo, al menos desde el año 1735 hasta 1767, salvo los años 1755 a $1757^{32}$. Fue regidor ${ }^{33}$ y alcalde mayor ${ }^{34}$ del cabildo municipal, y vivió en la calle Alcaudete, actual Padre Marchena, como uno de los hijosdalgos de la villa ${ }^{35}$. Casado con Dionisia de Reina, no tuvo descendencia, testó en septiembre de 1764 y pidió ser enterrado en el hueco de la capilla de la Vera Cruz y en el nicho que tenía separado y situado a los pies del Crucificado ${ }^{36}$. Falleció en noviembre de $1770^{37}$. Por su parte, José Hidalgo, estuvo de mayordomo desde el año 1747 hasta el año $1762^{38}$. Aunque en el padrón de 1753 había varios vecinos de la localidad que se llamaban José Hidalgo, con toda probabilidad, el mayordomo de la hermandad debía ser un labrador que vivía en la calle Huerta Gavira, casado con Josefa Guimil, familia muy devota del Señor de la Santa Vera Cruz $^{39}$. José Hidalgo, hijo de Juan Hidalgo y María de Carmona, y Josefa Guimil, viuda de Miguel de Amil, contrajeron matrimonio en la parroquia de San Sebastián el día 25 de febrero de $1748^{40}$. Falleció en junio de 1787 y se enterró en

párroco don José Tomás Montes Álvarez y al párroco emérito don Juan Ramón Gallardo Soriano por las facilidades dadas para la consulta documental.

${ }^{32}$ AHVCM, Libro de quentas..., s. f.

${ }^{33}$ En la portada del padrón de vecinos del año 1744 aparece "don Juan de Aguilar Galindo de Vega, rexidor”. AMM, Padrones, leg. 1305, Padrón del año 1744, f. 1r. Este realizó el padrón de vecinos del barrio de San Sebastián con don Pedro Díez de la Cortina, alcalde ordinario, y don Francisco Zenteno, alguacil mayor. Se hizo el 20 de noviembre de 1744.

${ }^{34}$ AMM, Actas Capitulares, leg. 14, año 1758, Acta de 16 de agosto, f. 229. Fue alcalde mayor durante los años 1757 y 1758. En el año 1744 vivía en la calle Albarracín según el padrón de ese año. AMM, Padrones, leg. 1305, Padrón del año 1744, f. 2r.

35 AMM, Padrones, leg. 1305, Padrón del año 1753, f. 12v. Así se inscribió en el padrón de vecinos: "n. 169. El señor don Juan de Aguilar y Galindo rejidor de primer boto en el Ayuntamiento de esta villa. Hijodalgo, casado con doña Dionicia de Reyna. Sin hijos".

${ }^{36}$ APNM, leg. 323, año 1764, ff. 312r-313v. En su testamento mandó se dijesen misas por sus padres Juan de Aguilar Galindo y Francisca Guillén, así como por el alma de su mujer Dionisia de Reina y por su cuñado Tomás Ignacio de Reina, presbítero y párroco de esta villa.

${ }^{37}$ APSJM, Defunciones, lib. 13, f. 237r. El día 17 de noviembre de 1770 se enterró en el hueco de la hermandad.

${ }^{38}$ AHVCM, Libro de quentas..., s. f.

39 AMM, Padrones, leg. 1305, Padrón del año 1753, f. 41v. En el no 816 del censo aparece "Joseph Hidalgo labrador, casado con Josepha Juimil tiene por su hijo a Francisco de dos años". Aparecen otros José Hidalgo en el padrón, entre ellos un zapatero que vivía en la calle La Mona, casado con Mariana Gutiérrez, sin hijos, y otro casado con Rosa de Utrera, también sin descendencia, que vivía en la calle Cochinos. AMM, Padrones, leg. 1305, Padrón del año 1753, ff. 60r y 62r.

40 Archivo Parroquial de San Sebastián de Marchena (APSSM), Libro de Desposorios $\mathrm{n}^{\circ} 10$, f. $218 \mathrm{r}$. Mi agradecimiento a su anterior párroco, don Antonio Ramírez Palacios $(\dagger)$, por las facilidades dadas para la consulta documental. 
la parroquia de San Sebastián con funeral de la hermandad de San Pedro ad Vincula ${ }^{41}$. Miguel Pérez de la Madrid ocupó el cargo de escribano de la corporación desde abril del año 1755 hasta diciembre de $1757^{42}$. Además fue regidor de la vi$1 a^{43}$. Vivió en la calle San Sebastián y estuvo casado con María Díaz y Zeballos, con quien por esas fechas tenía un hijo llamado Antonio ${ }^{44}$. Falleció en febrero de $1760^{45}$. Por su parte, Ignacio Francisco de Segura fue fiscal de la hermandad en esos años. Además fue notario mayor de la vicaría de Marchena, tal como se recogió en el padrón fechado en el año 1753 y, posteriormente, mayordomo de fábrica de la misma. Estaba casado con doña María Josefa López Becerra y vivía en la calle San Sebastián. Ese año, la unidad familiar se completaba con dos hijas, María y Manuela de tres años y tres meses respectivamente ${ }^{46}$. Falleció en enero de 1767 y también se enterró en la bóveda de la hermandad ${ }^{47}$.

Analizándolo formalmente, se trata de un retablo de madera dorada, policromada y estofada, ubicado y adaptado a la cabecera de la nave central de la capi1la, siendo la movilidad de la planta uno de sus aspectos más curiosos. El retablo barroco sevillano había pasado de una planta rectilínea a una planta cóncava mucho más movida que permitía que el fiel o espectador se viese envuelto por este. No obstante, esta máquina barroca está a medio camino entre un retablo completamente rectilíneo y otro completamente cóncavo, forzándose más esta última posición al trasladarse de lugar como se mostrará más adelante (Figura 2).

Está estructurado en zócalo, banco, cuerpo, tres calles y ático. El zócalo está realizado en madera pintada y estucada simulando jaspes rojos, decorado con marcos y figuras geométricas en tonos de bronces e incluyendo alguna decoración vegetal. La amplia mesa de altar presenta una decoración vegetal de grandes hojas de cardos, "ces", paños y guirnaldas junto a grandes cabezas de ángeles (Figura 3). El banco tiene un curioso manifestador que con posterioridad debió cobijar el sagrario que actualmente posee. El manifestador o tabernáculo era una pieza o elemento litúrgico que se situaba en aquellos retablos donde se exponía al

${ }^{41}$ APSJM, Defunciones, lib. 16, f. 40v. Se enterró el día 4 de junio de 1787. Practicó el funeral la hermandad de San Pedro ad Vincula, pues su hijo Francisco Hidalgo era subdiácono $\mathrm{y}$, por tanto, miembro de la hermandad de sacerdotes de la villa.

${ }^{42}$ AHVCM, Libro de quentas..., Años 1755-1757, s. f.

${ }^{43}$ AMM, Libro de Actas Capitulares, leg. 14, Año 1757.

${ }^{44}$ AMM, Padrones, leg. 1305, Padrón del año 1753, f. 32v.

${ }^{45}$ APSJM, Defunciones, lib. 13, f. 50r. Aunque la letra es prácticamente ilegible, se lee que se enterró el día 4 de febrero de ese año, desconociéndose en qué templo.

${ }^{46}$ AMM, Padrones, leg. 1305, Padrón del año 1753, f. 33r.

${ }^{47}$ APSJM, Defunciones, lib. 13, f. 150r. Se enterró el día 4 de enero de 1767. De su directa vinculación a la fábrica parroquial dan buena cuenta la elección de sus albaceas testamentarios, entre los que se encontraba su cuñado sacerdote Francisco López Bezerra, así como los restantes que también eran sacerdotes. En el mismo libro se recogen las misas ofrecidas por su alma. APSJM, Defunciones, lib. 13, ff. 316r-318v. 
Santísimo Sacramento unos días concretos del año o en algunos cultos, tal como los celebraba la hermandad crucera ${ }^{48}$. Se trata de un manifestador enmarcado por pequeños estípites con decoración de veneras y motivos florales en su tercio inferior, seis columnillas de orden compuesto, cuatro estriadas en dos tercios y con decoración de guirnaldas en el tercio superior, y dos columnas en la parte delantera de orden compuesto con fustes decorados por guirnaldas de flores que crean un espacio circular que permite su visión desde varios ángulos, creando cierto efectismo teatral (Figura 4). El cuerpo central del retablo está articulado por dos grandes columnas de orden compuesto, apoyadas por dos grandes ménsulas con pequeños ángeles atlantes. Están decoradas con guirnaldas, rosas de pasión, veneras, etc. El nicho principal se ubica entre dos estilizados estípites y dos cortinillas que caen a ambos lados desde la clave del arco de la hornacina. Las calles laterales se enmarcan por estípites rematados por fuentes con frutas que también podrían pertenecer al anterior retablo. En las hornacinas se sitúan las imágenes de Nuestra Señora de la Esperanza y San Juan Evangelista. Sobre aquellas aparece una gran cartela rodeada por decoración vegetal. Sobre unas ménsulas y a ambos extremos del retablo se sitúan dos imágenes de bulto redondo de San Pedro y San Pablo (Figura 5). El ático se separa del cuerpo principal gracias a tramos de cornisa mixtilínea en los que la profusa decoración permite ver la continuidad de la misma. De forma cóncava, presenta una hornacina en el centro con la escena de Santa Elena hallando la verdadera Cruz, que aparece sostenida por ángeles atlantes. La escena aparece rodeada por cartelas con distintos elementos pasionales rodeadas de decoración vegetal y numerosas cabezas de ángeles. Todo el ático se remata con una crestería en la que se combinan motivos vegetales que recuerdan a las clásicas acróteras o pequeñas cornisas en forma de frontón con cabezas de querubines. En el centro aparece una gran cartela sujeta por dos ángeles con la imagen de la Santa Faz, la lanza y la caña como hisopo (Figura 6).

Como ya se ha indicado, y aunque el soporte principal del retablo es el estípite, heredado de Jerónimo Balbás, también se utilizan dos grandes columnas que originan las tres calles principales del retablo. Se trata de un retablo de planta ochavada con una estructura muy clara aunque con una abigarrada ornamentación. En ella conviven muchos elementos tomados de la naturaleza, como la hoja de cardo, veneras, guirnaldas de flores y frutos junto a una rocalla incipiente en alguna zona concreta del retablo y que con posterioridad evolucionará hacia

${ }^{48}$ La hermandad de la Vera Cruz celebraba cultos solemnes con la exposición del Santísimo Sacramento en el manifestador del retablo durante varios días, tras la institución del jubileo circular en la localidad en junio de 1804. Ramos Suárez, 1999: 38. Gracias a un documento se pueden conocer los días habituales que la corporación celebraba el jubileo en su capilla, coincidiendo con los cultos que celebraba regularmente. El año 1821 festejó los días 11 de febrero y 1 y 3 de mayo. IC, AGAS, II. Gobierno, Asuntos Despachados, caja 4666, Vicaría de Marchena, s. f. 
formas más elaboradas y caprichosas. Por ello, los especialistas lo habían considerado un retablo pionero dentro del estilo rococó de la localidad dada su temprana cronología ${ }^{49}$. El autor del retablo fue posiblemente Tomás Guisado el Joven y su taller, teniendo en cuenta que este artista trabajó en esta localidad y en toda la campiña sevillana. Según la bibliografía artística, se sabe que el tallista vivió en la localidad en las décadas de los cuarenta y cincuenta del siglo XVIII ${ }^{50}$. Esto hace suponer que durante estos años muchos de los trabajos de los distintos templos fueron realizados por este escultor y su equipo ${ }^{51}$. La participación del taller es evidente cuando se aprecia que los distintos ángeles del retablo, tanto los de cuerpo entero como las cabezas de querubines, fueron realizados por distintas manos, apreciándose distintas calidades. Durante esos años se firmaron varios contratos en la localidad y, posiblemente, el firmado para la hermandad de la Salud de la iglesia parroquial de Nuestra Señora del Rosario de la ciudad de Cádiz fuese crucial para que el artista se desplazase a la ciudad gaditana, donde pudo conocer esas incipientes rocallas que materializó de forma discreta en algunas zonas concretas del retablo ${ }^{52}$. Otra circunstancia que señala a Guisado como artífice del retablo es su participación en la construcción del retablo mayor de la parroquia de San Sebastián en septiembre de 1760, que no llegó a materializarse. El contrato se firmó entre la fábrica parroquial, representada por su mayordomo, Ignacio Francisco de Segura, y el tallista. Además de darse la coincidencia de que el mayordomo de fábricas fuese también fiscal de la hermandad crucera, en la segunda cláusula de la escritura notarial del retablo parroquial se pidió que en vez de hacerle una mesa de altar se colocaría un repisón de tres varas más o menos de tamaño con la misma obra y talla que los repisones de la Virgen de los Desamparados, el del Cristo de San Pedro y el del Cristo de la Santa Vera Cruz, lo que viene a ratificar una vez más que Guisado y su taller acometieron la obra ${ }^{53}$, amén de otras obras documentadas del autor en el mismo entorno ${ }^{54}$.

Iconográficamente se muestra la Pasión de Cristo. Es una representación del monte Calvario con Cristo crucificado en el centro, la Virgen con la advocación de la Esperanza en el lado del evangelio y la imagen de San Juan Evangelista en el lado de la epístola. A ello se une la colocación de cartelas con motivos pasionales como la escala, los azotes, los clavos y la caña con el hisopo o la lanza junto al lienzo de la Santa Faz en su remate. No obstante, se trata de una visión celeste del momento de la crucifixión de Cristo en la que numerosos ángeles y jerarquías celestes rodean la escena. Esa gloria con ángeles inunda todos los espacios del

\footnotetext{
49 Recio, 2000: 472.

${ }^{50}$ Mira Caballos/De la Villa Nogales, 1996: 171-188.

${ }^{51}$ Para conocer más sobre la vida y obra de los Guisado, Herrera García, 2001: 449-467.

52 Recio, 2000: 215.

${ }^{53}$ Ramos Suárez, 2014: 52-53.

${ }^{54}$ Recio, 2000: 215-216.
} 
retablo desde el banco hasta la crestería del ático. Esta visión celestial se completa con la escena narrada por Rufino de Aquilea en la que Santa Elena, tras hacer un viaje a Tierra Santa, llegó al lugar donde según la visión cavaron y encontraron tres cruces. Al no saber cuál podía ser la de Cristo, se decidió presentarla a una mujer que estaba muy grave. El obispo Macario pidió que le acercasen las tres cruces. Tras aplicarle las tres cruces, en la última abrió los ojos y se levantó. De ahí que descubriesen cuál era la cruz de Jesús ${ }^{55}$. El conjunto se completa con la ubicación de dos imágenes a ambos lados del retablo. En el del evangelio, se sitúa la imagen de San Pedro y la de San Pablo, en el lado de la epístola. Casi tocando el techo de la capilla y a ambos lados del retablo, se colocaron dos ángeles lampareros de la misma época del mismo. Realizados en madera policromada y dorada aparecen vestidos con túnica de voluminosos pliegues mostrando un gran dinamismo. Están calzados anacrónicamente con unas grebas romanas como si fuesen guerreros celestiales, más del gusto romano que del estilo barroco. La cabeza se toca con unas plumas y una diadema dorada. Sin embargo, resulta extraña su alta ubicación, lo que hace suponer que este no fue su primitivo emplazamiento. Están colocados de lado para adaptarse a las paredes laterales del retablo, si bien lo lógico sería que mirasen al espectador. De ese modo, las manos que sujetaban las lámparas estarían más cerca del retablo, iluminando a las imágenes titulares.

En definitiva, se representa la exaltación de la verdadera Cruz tomando como base el Crucificado de la Vera Cruz. Dada la ubicación y la situación del retablo, el fiel da culto a la imagen y es partícipe de la escena, encontrándose dentro de la misma. Con esa estructura envolvente, se crea un efectismo teatral, se crean diversos planos visuales y espacios fingidos gracias al uso de espejos, sobre todo, en el manifestador.

Nuevas reformas se produjeron en el retablo a lo largo del siglo XIX. Así, en los años 1831 y 1832 se vendió la reja del camarín por un importe de 200 reales. Esto hace suponer que el camarín estuvo cerrado por una cristalera que preservó la imagen del Crucificado ${ }^{56}$. Sin embargo, fue tras la exclaustración y desamortización de Mendizábal cuando el retablo debió sufrir una nueva transformación. En el año 1844 se procedió a la venta de las dependencias del convento, aprobándose la conservación del templo. Debido al deterioro de la bóveda de la iglesia, esta se cerró en febrero de 1846. El cabildo municipal, siendo consciente de la situación céntrica del templo, de las hermandades establecidas y su devoción, propuso una suscripción para su restauración. Un mes más tarde, la hermandad de

55 Réau, 1997: 427. Se trata de la historia de Rufino de Aquilea, traducida por Claude Seyssel en el año 1597. A esta versión se une la variante en la que es una mujer difunta la que resucitó, siendo esta más acorde con la visión presentada en este retablo, pues donde se encuentra la mujer parece más un ataúd que una cama.

${ }^{56}$ AHVCM, Libro de Intervención. Marzo 1827- abril 1855, Cargo de julio 1831-abril 1832, s. f. 
la Vera Cruz pidió la apertura de su capilla, pues era independiente del templo franciscano. Tras dirigirse a la autoridad eclesiástica y haberse practicado el pertinente informe por parte de los alarifes locales, la capilla se mantuvo abierta. Sin embargo, la noche del 9 de noviembre de 1846 se desplomó más de la mitad de la bóveda de la iglesia. Aunque hubo intentos de recuperarla, no se pudo llevar a cabo. En febrero de 1848, el cabildo municipal recibió un comunicado del administrador de bienes nacionales por el que la iglesia pasó a formar parte de las fincas del Estado. Eso hizo que también se subastase el templo y su sacristía. Al año siguiente, en septiembre de 1849, tres hermanos de la corporación adquirieron parte del antiguo templo para ampliar la capilla. Eso permitió hacer una capilla más amplia, de tres naves, con una nueva distribución y con necesidad de dotarla de retablos para cubrir sus muros. Fue entonces cuando solicitaron los retablos del ex convento de Santa Eulalia ${ }^{57}$. Años más tarde, en marzo de 1858, la capilla se había transformado abriéndose al culto. Todo hace suponer que la construcción de la nueva capilla obligó a una redistribución de los bienes muebles, considerándose el de más importancia el retablo mayor de la hermandad. Esto plantea la hipótesis de que el retablo no estuviese en su lugar primitivo, y que fuese trasladado a este nuevo lugar, máxime cuando las calles laterales se presentaban más inclinadas de lo habitual. Este planteamiento quedó corroborado por los restauradores cuando observaron zonas doradas que aparecían ocultas a la vista de los fieles. También constataron cómo la estructura interna del retablo no obedecía a una construcción y ensamblajes propios del siglo XVIII sino, más bien, a un arreglo o reubicación posterior de los elementos internos del retablo realizado con poca maestría. Además, como se ha expuesto, resulta extraña la posición que tienen los ángeles lampadarios, pues ni están bien situados para sostener las lámparas, ni el lugar tan cercano al retablo es el más a propósito para colocarlos.

Por esas fechas, el sagrario también debió adaptarse al hueco del manifestador. Se trata de un sagrario reaprovechado quizás de otro retablo del templo franciscano tras su destrucción, o quizás proveniente de otro lugar, pues era necesario para reservar el sacramento en la nueva capilla. Esa reutilización se aprecia en las mutilaciones del remate de la corona o en las cortinas laterales. La puerta del sagrario aparece decorada por un Cordero pascual con banderola entre sus patas delanteras, sobre el libro de los siete sellos que representa a los siete sacramentos. La puerta está orlada por una corona real y dos cortinas que parten de ella, colgando a ambos lados de la misma. En su parte baja lleva un tirador para extraerlo del manifestador con más facilidad. Así, ese espacio del banco tenía una doble utilidad, bien para exponer el sacramento o bien para reservarlo. Una vez remozada la nueva capilla y ubicado el retablo en el lugar

${ }^{57}$ Para conocer más detalladamente este proceso, Ramos Suárez, 2008: 265-268 y 356-357. 
actual, la hermandad hizo gestiones para recibir el beneplácito espiritual con la concesión de indulgencias ${ }^{58}$.

Posteriormente, en los años que van desde 1868 hasta 1873, se hicieron varios pagos a Martín Ojeda "por el dorado de la repisa del Señor". Los importes ascendieron a un total de 1.228 reales $^{59}$. Esa reforma coincidió con la transformación del camarín del Señor en su parte frontal. La decoración simétrica del frontal se centró en delimitar con baquetones sencillos el lugar donde se colocó la cruz. Alrededor se situaron estrellas doradas. El frontal se rodeó de una sobria cenefa que alterna motivos vegetales y rosas de pasión. A la altura de las rodillas del Crucificado hay dos cartelas romboidales con una escalera y un corazón con tres clavos, motivos que se repetirán en la peana. Durante varias décadas este frontal estuvo cubierto de un terciopelo verde que impedía ver la decoración, pero que resaltaba la imagen del Crucificado. Por su parte, la peana dorada presenta forma troncopiramidal y está decorada con varias cenefas simétricas de gusto neoclásico y con decoración vegetal de hojas de helechos sobrepuestas. A ello hay que añadir unas estrellas en bajorrelieve dorado junto a un corazón con los tres clavos en su parte central o una escalera dentro de un tondo. En su parte baja, presenta dos cubiletes para colocar unos cirios.

En el año 1900, se procedió a realizar una composición de carpintería en la mesa de altar del Señor y en el arreglo de un banquillo, sin saber muy bien a qué mueble se refiere. La reforma debió ser considerable, pues se abonaron más de 118 reales ${ }^{60}$. A lo largo de ese siglo, el retablo debió sufrir algunos reparos o limpiezas

${ }^{58}$ Se concedió indulgencia a la imagen del Crucificado. Fue dada por Calisto Castrillo y Ornedo, entonces obispo de Doliche (Grecia) y obispo auxiliar de la archidiócesis de Sevilla, en visita pastoral realizada en julio de 1862. Esta indulgencia aparece recogida en un cuadro situado en las paredes de la capilla.

${ }^{59}$ Los libros contables recogen cinco pagos a Martín Ojeda por el dorado del camarín del Crucificado. En 1868-1869 se le abonan 400 reales; en 1869-1870, 100; en 1870-1871, 200; entre 1871-1872, 328; y, entre 1872-1873, se le liquidaron 200. AHVCM, Libro de cuentas. Años 1866-1900, Datas de los años mencionados. Curiosamente fue Martín Ojeda quien en los años 1874-1875 colocó unas pestañas a la Virgen de la Esperanza. Ya se tenía conocimiento de la actividad que desempeñaba el mencionado Ojeda en otras hermandades, caso de la hermandad de la Soledad, pues la casa ducal costeó el Crucificado articulado que recientemente se ha recuperado para el acto del descendimiento. Ramos Suárez, 2008: 255.

${ }^{60}$ AHVCM, Libro de cuentas. Junio 1901- junio 1912, Data de los años 1900-1901, s. f. Por esas fechas también se concedieron nuevas indulgencias. Es el caso de la del paisano don José María Salvador Barrera, obispo de Madrid-Alcalá, en mayo de 1902, coincidiendo con la fiesta de la Exaltación de la Cruz, o a la promulgada en septiembre de 1909 por don Enrique Almaraz y Santos, arzobispo de Sevilla, a los que rezasen a las imágenes del Crucificado y la Virgen de la Esperanza. Estas indulgencias aparecen recogidas en unos cuadros situados en las paredes de la capilla. 
desafortunadas, caso de la producida cuando se remozó la capilla en la segunda mitad del siglo XX, los deterioros propios de colocar altares efímeros sobre este y la exposición constante a los humos de los cirios, entre otros. Afortunadamente, con el inicio de esta década, el retablo ha sido sometido a un proceso de restauración científica ofreciendo, tras la intervención, la imagen que antaño debió tener esta arquitectura en madera que alberga unas imágenes de gran devoción en la localidad ${ }^{61}$.

Fecha de recepción: 29 de octubre de 2019

Fecha de aceptación: 13 de abril de 2020

\section{BIBLIOGRAFÍA}

Arenillas, Juan Antonio (1989): "Juan del Castillo, un escultor del siglo XVIII en Marchena". En: Atrio, 1, pp. 81-84.

(1990): Arquitectura civil en Marchena durante el siglo XVIII. Marchena: Ayuntamiento.

Carmona Perea, José Enrique (2010): Santa Vera Cruz de Marchena. Legado de una Hermandad. Marchena: Hermandad de la Vera Cruz.

Gestoso y Pérez, José (1899): Ensayo de un diccionario de los artífices que florecieron en Sevilla, desde el siglo XIII al XVIII inclusive. Sevilla: Oficina de la Andalucía Moderna, t. III.

Halcón, Fátima/Herrera, Francisco/Recio, Álvaro (2000): El retablo barroco sevillano. Sevilla: Universidad de Sevilla/Fundación el Monte.

(2009): El retablo sevillano. Desde sus orígenes hasta la actualidad. Sevilla: Diputación Provincial/Fundación Real Maestranza de Caballería/Fundación Cajasol.

Herrera García, Francisco J. (2001): El retablo sevillano en la primera mitad del siglo XVIII: evolución y difusión del retablo de estípites. Sevilla: Diputación.

Mira Caballos, Esteban/De la Villa Nogales, Fernando (1993): Documentos inéditos para la historia del arte en la provincia de Sevilla. Siglos XVI al XVIII. Carmona: Ayuntamiento.

(1996): "Los Guisado, una familia de escultores en la archidiócesis sevillana”. En: Archivo Hispalense, 242, pp. 171-188.

Ramos Suárez, Manuel Antonio (1999): El patrimonio cultural de Marchena y la ocupación napoleónica. Marchena: Ayuntamiento.

${ }^{61}$ La restauración se efectuó entre los años 2010 y 2011 por un equipo de profesionales dirigidos por los restauradores José María Calderón y Paloma Maza. 
(2001): "Juan del Castillo y Francisco Casaus, retablistas en la iglesia de san Juan Bautista de Marchena (Sevilla)". En: Laboratorio de Arte, 14, pp. 259274.

(2008): Patrimonio cultural y Desamortización. Marchena, 1798-1901. Sevi1la: Diputación Provincial.

(2014): La parroquia de San Sebastián Mártir de Marchena. Sevilla: Maratania.

(2017): "De pleitos y retazos histórico-artísticos de las hermandades del Dulce Nombre de Marchena (Sevilla)". En: Aranda Doncel, Juan (coord.): Los dominicos y la advocación del Dulce Nombre de Jesús en Andalucía. Archidona: Archicofradía del Dulce Nombre, pp. 189-221.

Réau, Louis (1997): Iconografía de los Santos A-F. Barcelona: Ediciones del Serbal, t. 2, v. 3 . 


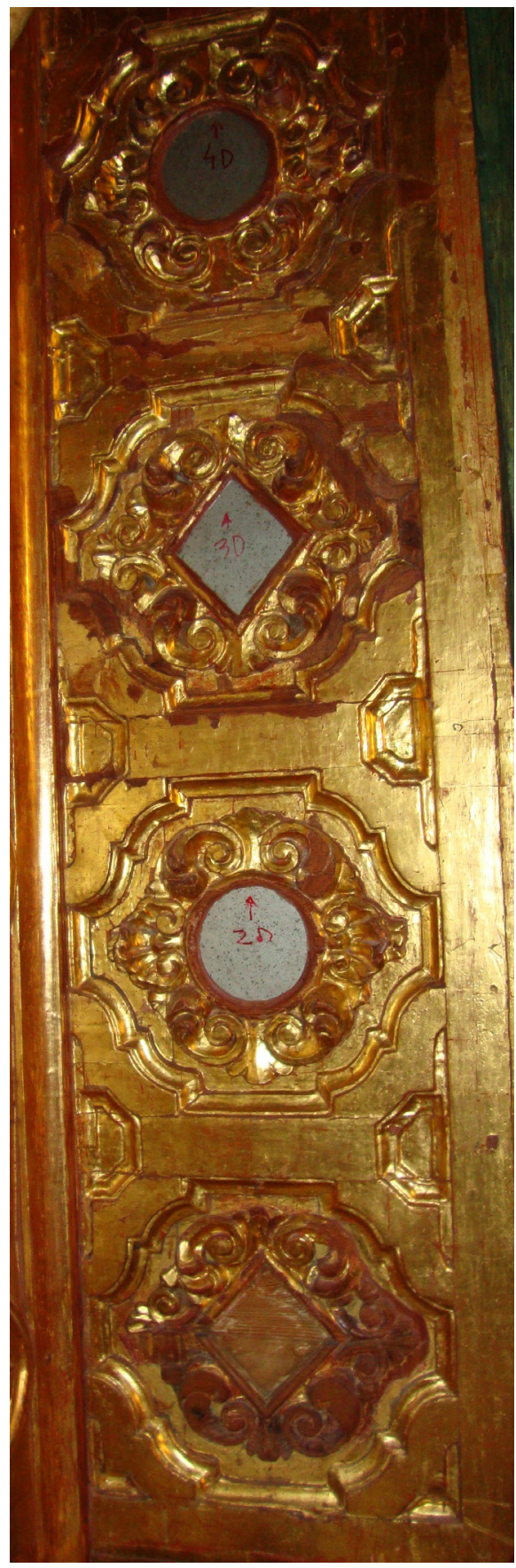

Figura 1. Anónimo,

Lateral de la hornacina principal del retablo mayor del Señor de la Santa Vera Cruz, primera mitad del siglo XVIII, capilla de la Vera Cruz, Marchena (Sevilla).

Foto: Manuel Antonio Ramos Suárez.

LABORATORIO DE ARTE 32 (2020), pp. 251-270, ISSN 1130-5762 e-ISSN 2253-8305 - DOI http://dx.doi.org/10.12795/LA.2020.i32.13 


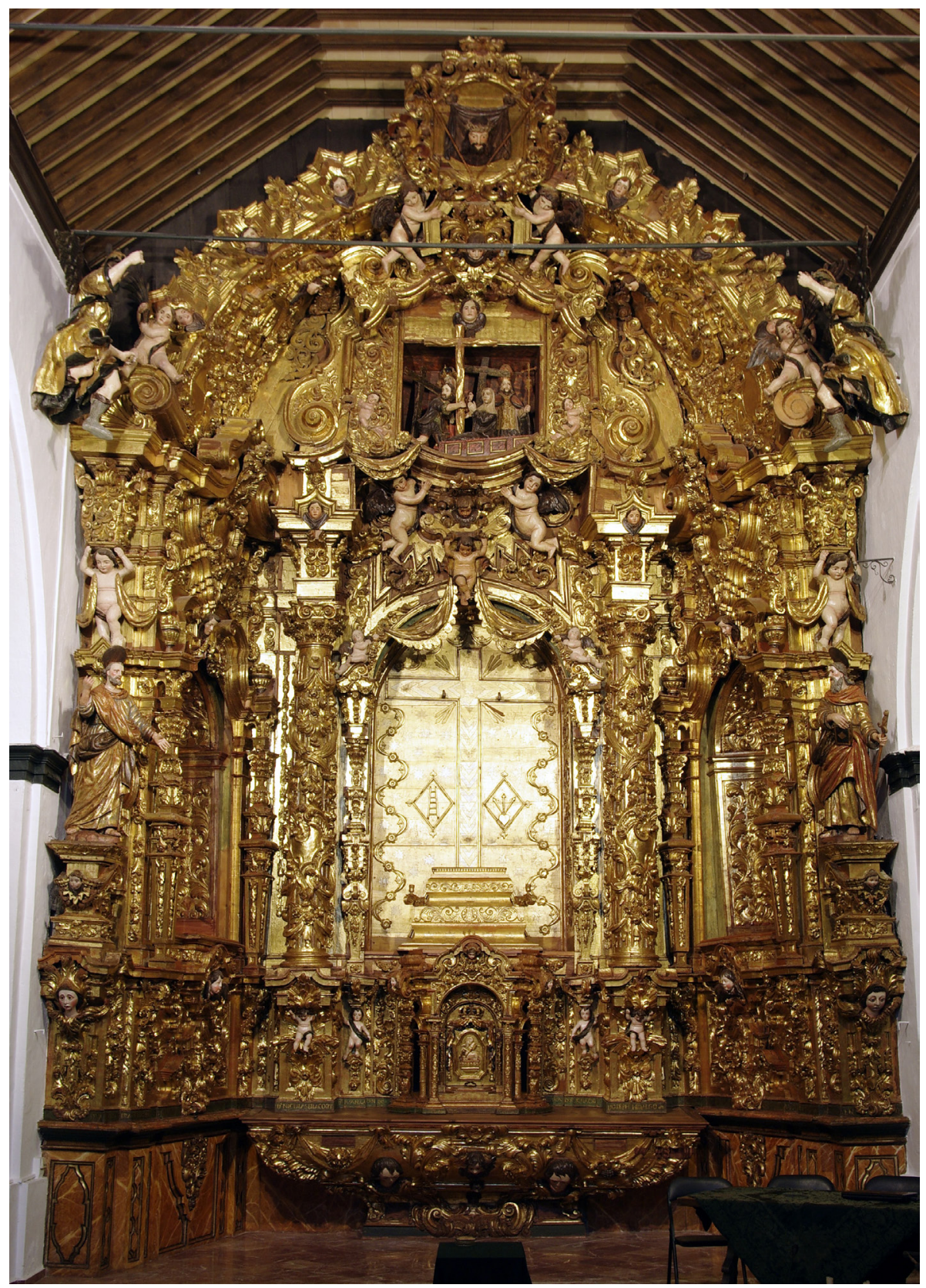

Figura 2. Tomás Guisado el Joven, Retablo mayor (tras la restauración del año 2010), 1759, capilla de la Vera Cruz, Marchena (Sevilla). Foto: José María Calderón Herrera. 


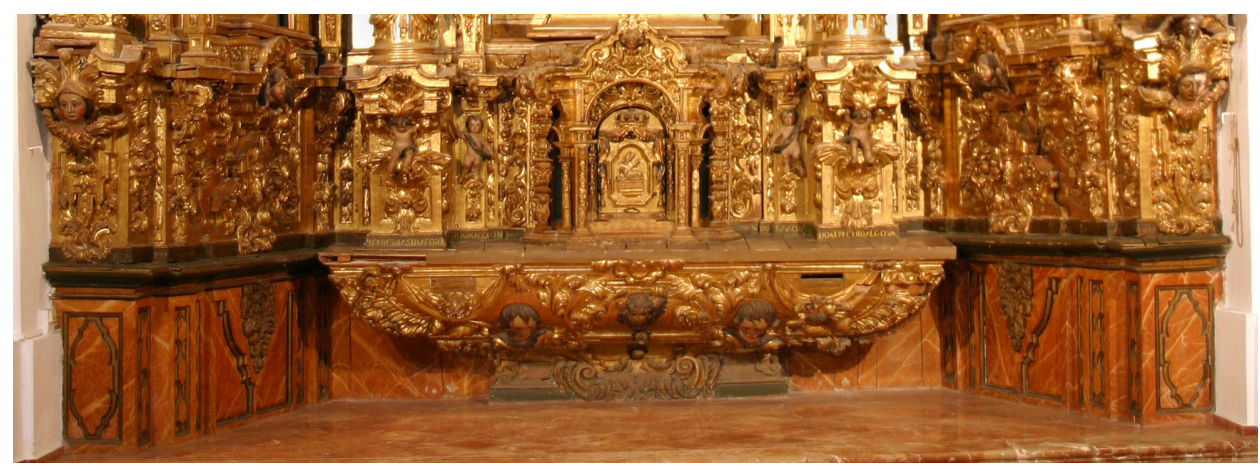

Figura 3. Tomás Guisado el Joven, Zócalo y mesa de altar del retablo mayor, 1759, capilla de la Vera Cruz, Marchena (Sevilla). Foto: Manuel Antonio Ramos Suárez. 


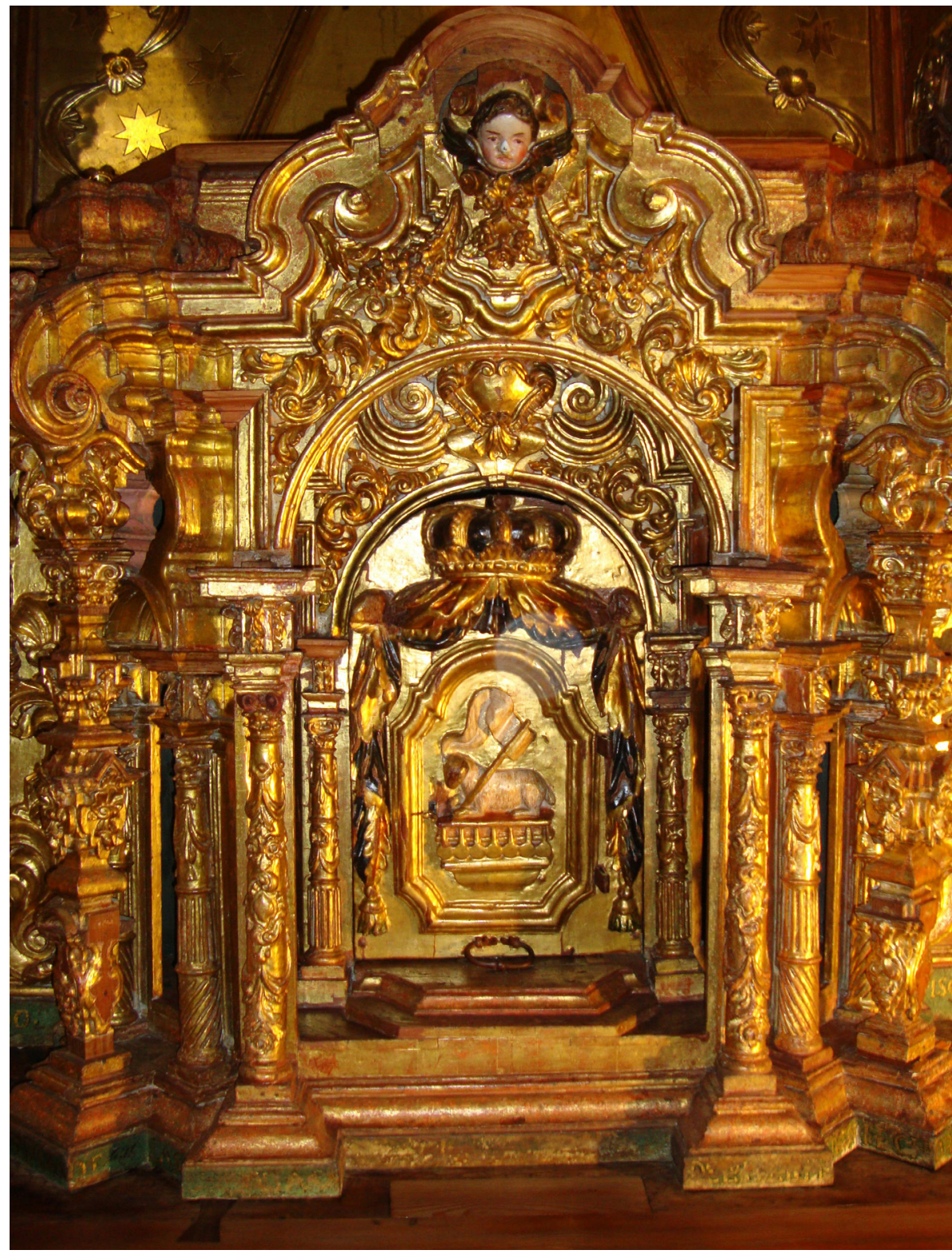

Figura 4. Tomás Guisado el Joven, Manifestador, 1759, y Anónimo, Sagrario (reutilizado de otro altar), primer tercio del siglo XVIII, capilla de la Vera Cruz, Marchena (Sevilla). Foto: Manuel Antonio Ramos Suárez. 


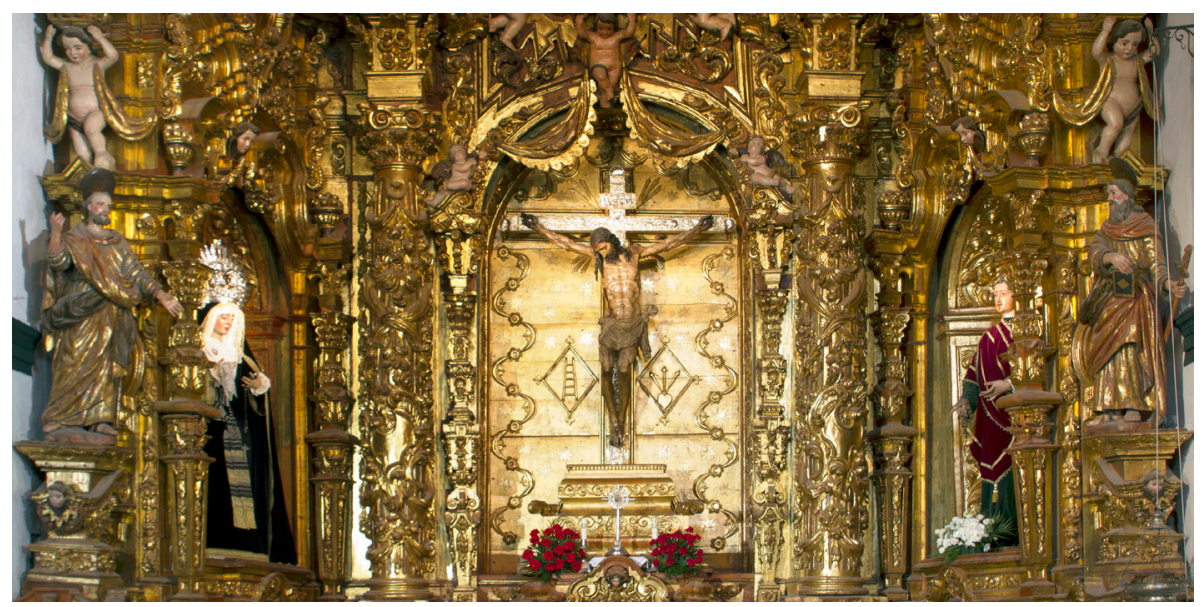

Figura 5. Tomás Guisado el Joven, Cuerpo principal del retablo mayor, 1759, capilla de la Vera Cruz, Marchena (Sevilla). Foto: José Enrique Carmona Perea.

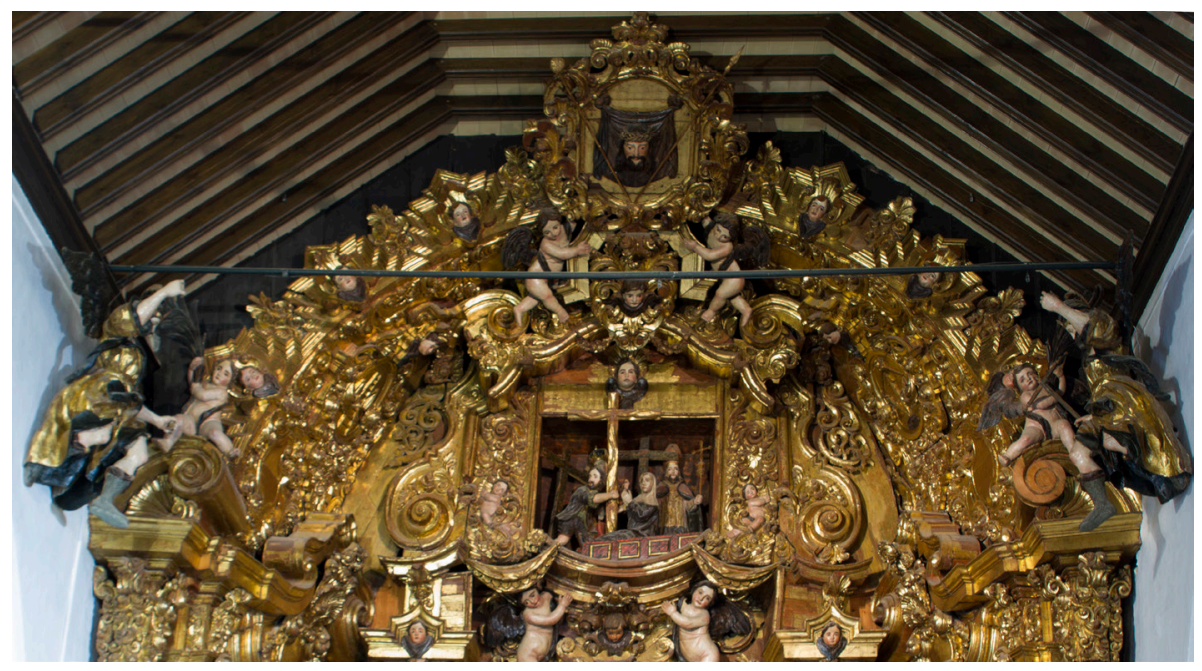

Figura 6. Tomás Guisado el Joven, Ático del retablo mayor, 1759, capilla de la Vera Cruz, Marchena (Sevilla). Foto: José Enrique Carmona Perea. 